\title{
EFEKTIVITAS BERKUMUR DENGAN LARUTAN INFUSUM KISMIS (VITIS VINIFERA L) TERHADAP PENURUNAN INDEKS PLAK GIGI
}

\author{
Elyasina $^{1}$, Rizanda Machmud $^{2}$, Murniwati ${ }^{3}$ \\ ${ }^{1}$ Mahasiswa Fakultas Kedokteran Gigi Universitas Andalas \\ ${ }^{2}$ Staf Pengajar Fakultas Kedokteran Universitas Andalas \\ ${ }^{3}$ Staf Pengajar Fakultas Kedokteran Gigi Universitas Andalas
}

\begin{abstract}
Plaque is the main factor in progress periodontal disease and dental caries. Plaque control is elimination and inhibit of dental plaque accumulation at tooth surface. Plaque control can be done mechanically and chemically. In this study, used a solution of raisin infusion (Vitis vinifera L) as a mouthwash, because there are various phytochemical capable of inhibiting plaque formation. The aim of this study was to know the effect of raisin infusion solution on decrease dental plaque index. This study is an experimental study with pretest and posttest control group design. The sample of this study was 56 students were divided randomly into four groups, which is one control group and three test groups. The test groups was given 20\%, 40\% and 60\% of raisin infusion solution. Dental plaque score was measured with PHP Plaque Index. Statistical analisys was performed according to Anova one way with $p<0,05$. The result of this study is significant differences of dental plaque index of control group when compared to the test group with $40 \%$ solution of raisin infusion $(p=0,004)$ and when compared to the test group with $60 \%$ solution of raisin infusion $(p=0,000)$. Rinsing with the $40 \%$ and $60 \%$ solution of raisin infusion can reduction of dental plaque index.
\end{abstract}

Keyword : dental plaque, the solution of raisin infusion.

Affiliasi penulis: ${ }^{3}$ Staf Pengajar Fakultas

Kedokteran Gigi Universitas Andalas

Korespondensi: Murniwati

email: murniwatihabib@yahoo.com

\section{PENDAHULUAN}

Masalah terbesar yang dihadapi penduduk Indonesia di bidang kesehatan gigi dan mulut adalah karies gigi dan penyakit periodontal. Berdasarkan data Riskesdas tahun 2013, prevalensi masalah kesehatan gigi dan mulut di Sumatera Barat meningkat menjadi $22,2 \%$, dimana penyakit yang paling banyak ditemukan adalah karies gigi dan penyakit periodontal. Data ini juga menunjukkan bahwa indeks DMF-T (Decay Missing Filled Teeth) untuk Provinsi Sumatera Barat adalah sebesar
4,7 yang menunjukkan bahwa kerusakan gigi masyarakat Sumatera Barat adalah sebanyak 470 gigi per 100 orang. ${ }^{1}$

Penyakit periodontal dan karies sering dihubungkan dengan penumpukan plak pada gigi dan gingiva. ${ }^{2}$ Bakteri yang terdapat dalam plak yang terakumulasi pada permukaan gigi dan flora normal rongga mulut merupakan faktor primer karies gigi. Karies gigi dapat terbentuk melalui interaksi dari bakteri yang spesifik dengan unsur diet dalam dental plak. ${ }^{3}$ Suasana asam yang dihasilkan oleh mikroorganisme yang terkandung dalam plak inilah yang dapat membentuk karies, ${ }^{4}$ sedangkan odontal disebabkan karena 
rusaknya jaringan epitel dan jaringan ikat oleh mikroorganisme pada plak. ${ }^{5}$

Plak gigi merupakan deposit lunak yang melekat erat pada permukaan gigi, terdiri atas mikroorganisme yang berkembang biak dalam suatu matriks interseluler. Plak biasanya mulai terbentuk pada sepertiga permukaan gingiva dan pada permukaan gigi yang kasar. Plak yang melekat erat pada permukaan gigi dan gingiva berpotensi cukup besar untuk menimbulkan penyakit pada jaringan keras gigi maupun jaringan pendukungnya. Keadaan ini disebabkan karena plak mengandung berbagai macam bakteri dengan berbagai hasil metabolismenya. ${ }^{6}$

Mikroorganisme yang berperan dalam pembentukan plak gigi adalah bakteri yang mampu membentuk polisakarida ekstrasel dari genus Streptococcus, yang didominasi oleh Streptococcus mutans. Bakteri ini merupakan flora normal dalam rongga mulut dan dapat berubah menjadi patogen apabila terjadi peningkatan jumlah koloni yang berlebihan, sehingga pertumbuhannya harus dihambat agar tidak menjadi patogen. ${ }^{7}$

Kontrol plak merupakan upaya membuang dan mencegah plak dan sisa makanan dari rongga mulut. Upaya tersebut dapat dibedakan menjadi metode mekanis dan kimiawi. Kontrol plak mekanis dengan cara menyikat gigi baik menggunakan sikat gigi manual maupun sikat gigi elektrik. Sedangkan kontrol kimia salah satu metodenya adalah dengan menggunakan obat kumur yang dapat membersihkan mulut dari sisa-sisa makanan yang memiliki agen anti bakteri untuk mengurangi akumulasi plak. ${ }^{8}$

Obat kumur ada yang terbuat dari bahan kimia dan bahan alami yang masing-masing mempunyai kelebihan dan kekurangan. Bahan alami sudah banyak digunakan sebagai agen anti bakteri karena lebih aman, efektif dan lebih ekonomis. Menurut Bower CK, seperti yang ia tulis pada Journal of Food Science, banyak jenis buah-buahan yang berkhasiat menghambat pertumbuhan bakteri Streptococcus mutans secara in vitro, salah satunya adalah anggur. Banyak varietas anggur yang dapat dijadikan kismis. ${ }^{9}$

Kismis adalah buah anggur yang dikeringkan. Kismis mengandung polifenol, flavonoid, dan tinggi besi yang dapat bermanfaat bagi kesehatan manusia. Ada beberapa penyelidikan tentang senyawa antimikroba dalam kismis terhadap patogen oral. Dimana antimikroba pada kismis mempunyai 
kemampuan untuk menghambat pertumbuhan patogen oral. ${ }^{10}$

Sebuah studi yang dilakukan para peneliti dari University of Illinois, Chicago College of Dentistry, AS, menunjukkan bahwa konsumsi kismis membantu mencegah terjadinya gigi berlubang serta penyakit gusi. Kandungan asam oleanolik dan komponen fitokimia lainnya pada kismis dapat menghambat pertumbuhan bakteri Streptococcus mutans (sebagai bakteri utama dalam pembentukan plak gigi dan penyebab karies) dan Porphyromonas gingivalis serta Fusobacterium nucleatum (banyak hubungannya dengan penyakit periodontal). ${ }^{11}$

Asam oleanolik disini menghambat proses glucosyltransferase (GTF), yaitu proses perubahan sukrosa menjadi glukosa dan fruktosa sehingga kolonisasi dan perlekatan bakteri ke permukaan gigi jadi berkurang. Penelitian lain yang terkait dengan kismis juga sudah dilakukan oleh Joshua Calvin tentang daya antimikroba infusum kismis terhadap pertumbuhan Streptococcus mutans secara in vitro. Dari hasil penelitiannya, Streptococcus mutans terhambat pertumbuhannya oleh infusum kismis dengan konsentrasi 30\% (Kadar Hambat Minimum/ KHM) dan akan mati pada konsentrasi 60\% (Kadar Bakterisid Minimum/ KBM). ${ }^{12}$

Mengkonsumsi kismis juga dapat mengurangi jumlah bakteri Streptococcus mutans, Lactobacilli, dan Porphyromonas gingivalis pada plak gigi. ${ }^{13}$

Berdasarkan uraian di atas, peneliti tertarik untuk melakukan penelitian mengenai manfaat kismis (Vitis vinifera L) dalam bentuk larutan infusum terhadap indeks plak gigi.

\section{METODE}

Penelitian ini bertujuan untuk mengetahui manfaat berkumur dengan larutan infusum kismis (Vitis vinifera L) $20 \%$, 40\% dan $60 \%$ terhadap indeks plak gigi. Penelitian ini merupakan penelitian eksperimental klinik dengan rancangan pretest and posttest control group design yang dilakukan di SMA DR. H. Abdullah Ahmad PGAI Padang pada bulan Februari tahun 2015. Sampel penelitian ini adalah 56 siswa SMA PGAI. Pemilihan sampel menggunakan metode simple random sampling, dimana sampel tersebut harus memenuhi kriteria inklusi dan eksklusi. Kemudian sampel dibagi secara acak menjadi 4 kelompok perlakuan, dimana ada 12 orang untuk setiap kelompok. Pengumpulan data penelitian ini dilakukan dalam dua hari. Hari 
pertama dilakukan pemilihan sampel dan demonstrasi cara penyikatan gigi dengan teknik kombinasi (Scrub dan Stillman).

Pada hari kedua sampel diberi perlakuan berkumur. Kelompok 1 sampel berkumur menggunakan aquades, kelompok 2 berkumur menggunakan larutan infusum kismis 20\%, kelompok 3 berkumur menggunakan larutan infusum kismis $40 \%$, dan kelompok 4 berkumur menggunakan larutan infusum kismis 60\%. Sampel diinstruksikan untuk tidak makan dan berkumur selama 3 jam dan kemudian dilakukan pemeriksaan skor indeks plak pada sampel menggunakan indeks plak PHP. Kemudian data dianalisa menggunakan uji Anova one way.

\section{HASIL PENELITIAN}

\begin{tabular}{|c|c|c|c|c|c|}
\hline Variabel & $\mathbf{n}$ & $\begin{array}{c}\text { Indeks } \\
\text { plak } \\
\text { sebelum }\end{array}$ & $\begin{array}{c}\text { Indeks } \\
\text { plak } \\
\text { sesudah }\end{array}$ & $\begin{array}{c}\text { Selisih } \\
\text { indeks } \\
\text { plak }\end{array}$ & p \\
\hline & & $\mathrm{X} \pm \mathrm{SD}$ & $\mathrm{X} \pm \mathrm{SD}$ & $\mathrm{X} \pm \mathrm{SD}$ & \\
\hline Aquades & 14 & $\begin{array}{c}2,90 \pm \\
0,63\end{array}$ & $\begin{array}{c}1,96 \pm \\
0,47\end{array}$ & $\begin{array}{c}0,94 \pm \\
0,27\end{array}$ & \multirow{4}{*}{0,000} \\
\hline $\begin{array}{l}\text { Kismis } \\
20 \%\end{array}$ & 14 & $\begin{array}{c}2,10 \pm \\
0,63\end{array}$ & $\begin{array}{c}1,13 \pm \\
0,56\end{array}$ & $\begin{array}{c}0,97 \pm \\
0,24\end{array}$ & \\
\hline $\begin{array}{l}\text { Kismis } \\
40 \%\end{array}$ & 14 & $\begin{array}{c}2,33 \pm \\
0,91\end{array}$ & $\begin{array}{c}0,80 \pm \\
0,48\end{array}$ & $\begin{array}{c}1,52 \pm \\
0,52\end{array}$ & \\
\hline $\begin{array}{l}\text { Kismis } \\
60 \%\end{array}$ & 14 & $\begin{array}{c}2,86 \pm \\
0,97\end{array}$ & $\begin{array}{c}0,92 \pm \\
0,57\end{array}$ & $\begin{array}{c}1,94 \pm \\
0,56\end{array}$ & \\
\hline
\end{tabular}

Tabel 1 Distribusi Rata-Rata Indeks Plak Berkumur dengan Aquades dan Larutan Infusum Kismis

Dari tabel 1 dapat dilihat bahwa terjadi penurunan rata-rata indeks plak setelah berkumur dengan aquades dan larutan infusum kismis. Penurunan rata- rata indeks plak paling besar terjadi pada responden yang berkumur dengan larutan infusum kismis $60 \%$ yaitu sebesar 1,94.

Dan penurunan rata-rata indeks plak paling kecil terjadi pada responden yang berkumur dengan larutan infusum kismis 20\% yaitu sebesar 0,97. Dan hasil paired t-test menunjukkan nilai $\mathrm{p}=0,000$ yang artinya terdapat perbedaan yang bermakna dari indeks plak sebelum dan setelah perlakuan berkumur menggunakan aquades dan larutan infusum kismis.

\begin{tabular}{lccc}
\hline $\begin{array}{c}\text { Kelompok } \\
\text { (I) }\end{array}$ & $\begin{array}{c}\text { Kelompok } \\
\text { (J) }\end{array}$ & $\begin{array}{c}\text { Mean } \\
\text { Difference } \\
(\mathrm{I}-\mathrm{J})\end{array}$ & $\mathrm{p}$ \\
\hline Aquades & Kismis 20\% & 0,035 & 1,000 \\
& Kismis 40\% & 0,58 & $0,004^{*}$ \\
& Kismis $60 \%$ & 1,002 & $0,000^{*}$ \\
Kismis & Kismis 40\% & 0,55 & $0,007^{*}$ \\
$20 \%$ & & & \\
& Kismis $60 \%$ & 0,96 & $0,000^{*}$ \\
Kismis & Kismis 60\% & 0,41 & 0,082 \\
$40 \%$ & & & \\
\hline $\mathrm{P}<0,05$ & & &
\end{tabular}

Tabel 2 Hasil Uji Multipel Komparasi Bonferroni Selisih Hasil Rata- Rata Indeks Plak Berkumur Menggunakan Aquades dengan Berkumur Menggunakan Larutan Infusum Kismis

Dari tabel 2 menunjukkan bahwa ada perbedaan yang bermakna selisih hasil rata-rata indeks plak antara berkumur aquades dengan larutan 
infusum kismis $60 \% \quad(\mathrm{p}=0,000)$, berkumur aquades dengan larutan infusum kismis $40 \% \quad(\mathrm{p}=0,004)$, berkumur dengan larutan infusum kismis 20\% dan 60\% ( $=0,000)$ dan berkumur dengan larutan infusum kismis $20 \%$ dan $40 \%$ ( $\mathrm{p}=0,007)$.

\section{PEMBAHASAN}

Dalam penelitian ini, efektivitas berkumur dengan larutan infusum kismis dalam menurunkan indeks plak gigi secara klinis diamati dengan menggunakan larutan infusum kismis konsentrasi 20\%, 40\% dan 60\%, serta berkumur dengan aquades sebagai kontrolnya. Sebagai tolak ukurnya digunakan indeks plak untuk mengukur skor plak masing-masing perlakuan pada setiap subjek penelitian. Indeks plak yang digunakan dalam penelitian ini adalah indeks plak PHP.

Dari data yang didapatkan, terlihat adanya perbedaan penurunan indeks plak antara perlakuan dengan aquades, larutan infusum kismis $20 \%$, $40 \%$ dan $60 \%$ pada enam permukaan gigi. Kemudian hasil antara setiap perlakuan dibandingkan satu sama lain untuk melihat mana yang paling efektif dalam menurunkan indeks plak gigi.

Berdasarkan hasil penelitian ini, didapatkan hasil bahwa setelah berkumur dengan larutan infusum kismis 40\% dan $60 \%$ terjadi penurunan indeks plak secara signifikan, namun antara larutan infusum kismis $40 \%$ dan $60 \%$ tidak ada perbedaan yang signifikan. Sedangkan setelah berkumur dengan larutan infusum kismis $20 \%$ dan dengan aquades tidak terjadi penurunan indeks plak secara signifikan. Itu artinya berkumur dengan larutan infusum kismis $40 \%$ dan $60 \%$ efektiv dalam menurunkan indeks plak gigi.

Berkumur dengan aquades tidak terjadi penurunan yang signifikan, hal ini dikarenakan berkumur dengan aquades yang tidak mengandung antibakteri hanya melarutkan dekstran ikatan $\alpha$ (1-6) pada plak gigi namun tidak menghambat pertumbuhan dan aktivitas bakteri yang terus membentuk plak baru setiap saat. ${ }^{14}$

Sesuai dengan teori yang dikemukakan oleh Pintaulli dan Hamada pada tahun 2010 bahwa pengendalian plak secara mekanis yang berupa penyikatan gigi dan flossing dapat disertai dengan upaya tambahan seperti penggunaan obat kumur untuk memberikan efektivitas pembersihan rongga mulut. ${ }^{15}$ Secara umum obat kumur merupakan larutan atau cairan yang digunakan untuk membilas rongga mulut dengan tujuan untuk 
membersihkan sisa makanan yang dapat menyebabkan plak yang tidak terjangkau ketika menyikat gigi, menghilangkan bau tak sedap, mempunyai efek terapi dan menghilangkan infeksi serta mencegah karies gigi. $^{14}$

Berkumur menggunakan larutan infusum kismis mengalami penurunan indeks plak yang signifikan dikarenakan kismis memiliki kandungan fenol dan asam oleanolik yang bersifat bakterisid terhadap bakteri pembentuk plak gigi. ${ }^{16}$ Kandungan fenol beserta senyawa turunannya seperti tannin dan flavonoid merusak membran sel bakteri dan menyebabkan kebocoran isi sel bakteri. ${ }^{17}$ Sedangkan asam oleanolik menghambat proses glucosyltransferase (GTF) bakteri sehingga perlekatan bakteri ke permukaan gigi menjadi berkurang. ${ }^{18}$

Hasil penelitian ini mendukung penelitian dari Joshua Calvin pada tahun 2008 yang menunjukkan bahwa kandungan kimia yang terdapat pada kismis mempunyai daya antimikroba terhadap Streptococcus mutans yang banyak ditemukan pada plak khususnya pada tahap pembentukan kolonisasi awal, sehingga dapat menurunkan indeks plak setelah berkumur dengan bahan ini. Berdasarkan penelitiannya,
Streptococcus mutans akan terhambat pertumbuhannya pada konsentrasi $30 \%$ infusum kismis dan bakteri tersebut akan mati pada konsentrasi $60 \%$ infusum kismis. ${ }^{12}$ Berkumur dengan larutan infusum kismis $40 \%$ dan $60 \%$ dapat menurunkan indeks plak karena pada konsentrasi tersebut Streptococcus mutans sudah terhambat pertumbuhannya. Sedangkan berkumur dengan larutan infusum kismis $20 \%$ tetap mengalami penurunan indeks plak tetapi tidak signifikan karena pada konsentrasi tersebut pertumbuhan bakteri belum terhambat.

Penelitian ini juga mendukung penelitian oleh Aldany tahun 2013 tentang efek mengunyah kismis terhadap bakteri di dalam plak pada pengguna pesawat ortodontik cekat umur 12-18 tahun. Penelitian ini membandingkan jumlah bakteri sebelum dan sesudah mengunyah kismis. Plak diambil setelah 30 menit mengkonsumsi kismis dan terjadi penurunan jumlah bakteri yang signifikan di dalam plak. Bakteri yang diisolasi pada penelitian ini adalah bakteri Streptococcus mutans, Lactobacilli dan Porphyromonas gingivalis, ${ }^{13}$ sehingga berkumur dengan larutan yang mengandung kismis dapat mengurangi bakteri pembentuk plak sehingga terjadi penurunan skor indeks 
plak gigi. Penelitian lain oleh Fausto Rivero tahun 2008 tentang efektivitas antimikroba ekstrak kismis terhadap bakteri Streptococcus mutans dan Porphyromonas gingivalis didapatkan bahwa 50\% konsentrasi ekstrak kismis dapat membunuh bakteri tersebut. ${ }^{18}$ Hal ini mendukung penelitian ini bahwa tidak ada perbedaan yang signifikan pada berkumur dengan larutan infusum kismis konsentrasi $40 \%$ dan $60 \%$ karena pada konsentrasi tersebut bakteri sudah mati.

\section{KESIMPULAN}

1. Terdapat perbedaan rata-rata indeks plak sebelum berkumur dengan larutan infusum kismis $20 \%$ dan sesudah berkumur dengan larutan infusum kismis $20 \%$.

2. Terdapat perbedaan rata-rata indeks plak sebelum berkumur dengan larutan infusum kismis $40 \%$ dan sesudah berkumur dengan larutan infusum kismis $40 \%$.

3. Terdapat perbedaan rata-rata indeks plak sebelum berkumur dengan larutan infusum kismis $60 \%$ dan sesudah berkumur dengan larutan infusum kismis $60 \%$.

4. Tidak terdapat perbedaan yang bermakna pada perlakuan berkumur aquades dengan larutan infusum kismis $20 \% \quad(\mathrm{p}=1,000)$. Terdapat perbedaan yang bermakna pada perlakuan berkumur aquades dengan larutan infusum kismis $40 \%(\mathrm{p}=0,004)$, pada perlakuan berkumur aquades dengan larutan infusum kismis $60 \%(\mathrm{p}=0,000)$, pada perlakuan berkumur larutan infusum kismis $20 \%$ dengan larutan infusum kismis $40 \% \quad(\mathrm{p}=0,007)$ dan pada perlakuan berkumur larutan infusum kismis $20 \%$ dengan larutan infusum kismis $60 \%$ $(\mathrm{p}=0,000) . \quad$ Pada perlakuan berkumur larutan infusum kismis $40 \%$ dengan larutan infusum kismis $60 \%$ tidak terdapat perbedaan yang bermakna $(\mathrm{p}=0,082)$ dan dapat disimpulkan bahwa berkumur dengan larutan infusum kismis $40 \%$ dan $60 \%$ efektiv dalam menurunkan indeks plak gigi.

\section{KEPUSTAKAAN}

1. Departemen Kesehatan RI. (2013). Laporan Hasil Riset Kesehatan Dasar (Riskesdas) Nasional. Badan Penelitian Dan Pengembangan Kesehatan Depkes RI. Jakarta.

2. Jain, Yashika. (2013). A Comparison of The Efficacy of Powered and Manual Toothbrushes in Controlling Plaque and Gingivitis: A Clinical Study. Clinical, Cosmetic and Investigational Dentistry. 
3. Chandrabhan, D., Hemlata, R., Renu, B., Pradeep, V. (2012). Isolation of Dental Caries Bacteria from Dental Plaque and Effect of Tooth Pastes on Acidogenic Bacteria. Open Journal of Medical Microbiology.

4. Ireland, Robert. (2006). Clinical Textbook of Dental Hygiene and Therapy. Blackwell Munksgaard. Oxford.

5. Carranza, F.A., Newman, M.G., Takei, H.H., Klokkevold, P.R. (2006). Carranza's Clinical Periodontology 10th ed. Saunders Elsevier. Missouri.

6. Putri, M.H., Hindrayati, E., Nurjanah, N. (2011). Ilmu Pencegahan Penyakit Jaringan Keras dan Jaringan Pendukung Gigi. EGC. Jakarta.

7. Felton, Ann., Chapman, Alison., Felton, Simon. (2009). Basic Guide to Oral Health Education and Promotion. Wiley Blackwell. United Kingdom.

8. Menon, Lakshmy., Ramamurthy, Jaiganesh. (2014). New Vistas in Plaque Control. IOSR Journal of Dental and Medical Sciences Volume 13, PP 64-68.

9. Wu, Christine. D. (2009). Grape Product and Oral Health. The Journal of Nutrition. American Society for Nutrition.

10. Mojabi, K. Borhan., Azimi, S. (2013). Antimicrobial Natural Product in Oral Health. Formatex.

11. Wong, Allen., et all. (2013). Raisins and Oral Health. Journal of Food Science vol 78. San Fransisco.

12. Calvin, Joshua. (2008). Daya Antimikroba Infusum Kismis terhadap Pertumbuhan Streptococcus mutans, in vitro. Fakultas Kedokteran Gigi Universitas Indonesia. Jakarta.

13. Aldany,A.A., et all. (2013). Evaluation of Natural Product for Maintaining Gingival Condition and Preventing Caries during Orthodontic Treatment:Part II: Raisin. Journal of American Science.

14. Akande, O. O., et all. (2004). Efficacy of Different Brands of Mouthrinses on Oral Bacterial Load Count in Healthy Adults. African Journal of Biomedical Research vol

7.

Ibadan.

15. Pintauli, S., Hamada, T. (2010). Menuju Gigi dan Mulut Sehat. USU Press.
Medan.

16. Shahidi, Fereidoon., Tan, Zhuliang. (2013). Raisin : Processing, Phytochemicals, and Health Benefits. Dried Fruits : Phytochemicals and Health Effects. John Wiley and Sons.

17. Carughi, Ariana. (2008). Health Benefits of Sun Dried Raisin. Review of The Scientifies Literature Trough July 2008.

18. Cruz, Rivero, Fausto., Zhu, Min., Kinghorn, Douglas., Wu, Christine. (2008). Antimicrobial Constituents of Thompson Seedless Raisin (Vitis vinifera) Against Selected Oral Pathogens. Elsevier. United States. 